\title{
7. LEG 44A, SITES 393, 394: BLAKE-BAHAMA BASIN
}

\author{
Shipboard Scientific Party ${ }^{1}$
}

\section{SITE DATA -393}

Dates Occupied: 11-21 November 1975

Position: $28^{\circ} 11.80^{\prime} \mathrm{N}$; $75^{\circ} 35.94^{\prime} \mathrm{W}$

Water Depth: 4951 meters (corrected PDR), 4957 meters (drill pipe)

Penetration: 58.5 meters

Number of Holes: 2

Number of Cores: 2

Total Length of Cored Section: 19 meters

Total Core Recovered: 19 meters

Percentage Core recovered: 100 per cent

Oldest Sediment Cored: Quaternary calcareous clay at 58 meters sub-bottom

Basement: Not reached

Principal Results: Site 393 was a re-occupation of Site 391 in the Blake-Bahama Basin. It was selected for the engineering trials because the soft bottom would provide a good test for the new type re-entry cone and because of the scientific importance of coring the older sediments and basement in the Blake-Bahama Basin.

Several technical failures resulted in poor recovery and the site was ultimately abandoned when the beacon failed. We recovered only 58.5 meters of Quaternary calcareous clays.

\section{SITE DATA - 394}

Dates Occupied: 22-24 November 1975

Position: $28^{\circ} 11.70^{\prime} \mathrm{N} ; 75^{\circ} 35.76^{\prime} \mathrm{W}$

Water Depth: 4957.0 meters (corrected PDR), 4951.5 meters (drill pipe)

Penetration: 364.5 meters

Number of Holes: 2

Number of Cores: 6

Total Length of Cored Section: 55 meters

Total Core Recovered: 17.3 meters

Percentage Core Recovered: 31.4 per cent

Oldest Sediment Cored: Miocene marly chalk at 364.5 meters sub-bottom.

Principal Results: Site 394 was drilled about 1000 feet southeast of Site 393 . We had only sufficient time to accomplish the higher priority technical objectives and took only six cores to fill gaps in the Site 391 sedimentary record. Cores 4,5 , and 6 were recovered from intervals previously unsampled at Site 391 . They contain Miocene carbonate gravity deposits as was expected on the basis of previous drilling.

\footnotetext{
${ }^{1}$ William E. Benson, R. James Kirkpatrick, John L. Usher.
}

\section{BACKGROUND AND OBJECTIVES}

\section{Background}

Sites 393 and 394 are essentially a re-occupation of Site 391 in the Blake-Bahama Basin (Figures 1 and 2). The Blake-Bahama Basin is of special geologic interest because it probably contains the oldest sediments underlying the Atlantic Ocean and because it is underlain by the "magnetic quiet zone." Drilling during DSDP Legs 1 and 11 penetrated the thinner sections around the margins of the basin, but penetration of the thicker central basin has awaited the availability of multiple re-entry capability and multichannel reflection profiles to show depth to basement structures (Figure 3). Both requisites were met by the summer of 1975 and Site 391 of Leg 44 was drilled in the basin in a well-documented part of the "magnetic quiet zone" (Figure 4 ) and at some distance from any known fracture zone. The site was further restricted to the flanks of a basement rise where the basement reflector at $1.43 \mathrm{sec}$ sub-bottom (1600-1700 m) was within reach of Glomar Challenger's drill string.

A technological failure in Hole 391A (Leg 44) required that the pipe be pulled at a sub-bottom depth of 659 meters, and when re-entry could not be achieved, Hole 391C was drilled to the destruction of a single bit, terminating in Upper Jurassic red limestone (ammonitico rosso).

Site 391 thus achieved several of its major objectives concerning the upper part of the geologic column, but failed to penetrate to the bottom of the sedimentary column and into the basement of the "quiet zone." Because of the overall importance of this site, the decision was made to re-occupy it and attempt to core the lower part of the section as part of the engineering trials of Leg 44A.

\section{Scientific Objectives}

The major scientific objectives at Sites 393 and 394, located within about a mile of Site 391, were: (1) to determine the character and age of the sediments below the Late Jurassic "ammonitico rosso," (2) to sample the volcanic basement near the western margin of the "magnetic quiet zone," and (3) to establish the age of some Middle or Lower Jurassic magnetic reversals to determine Jurassic spreading rates. A secondary objective was to recover cores from higher intervals unsampled at Site 391.

\section{OPERATIONS}

\section{Site 393}

Glomar Challenger left Norfolk, Virginia, at $1210^{2}$ hours on 8 November 1975 to begin Leg 44A. Enroute to Site 393,

\footnotetext{
${ }^{2}$ Time given in text is local time.
} 


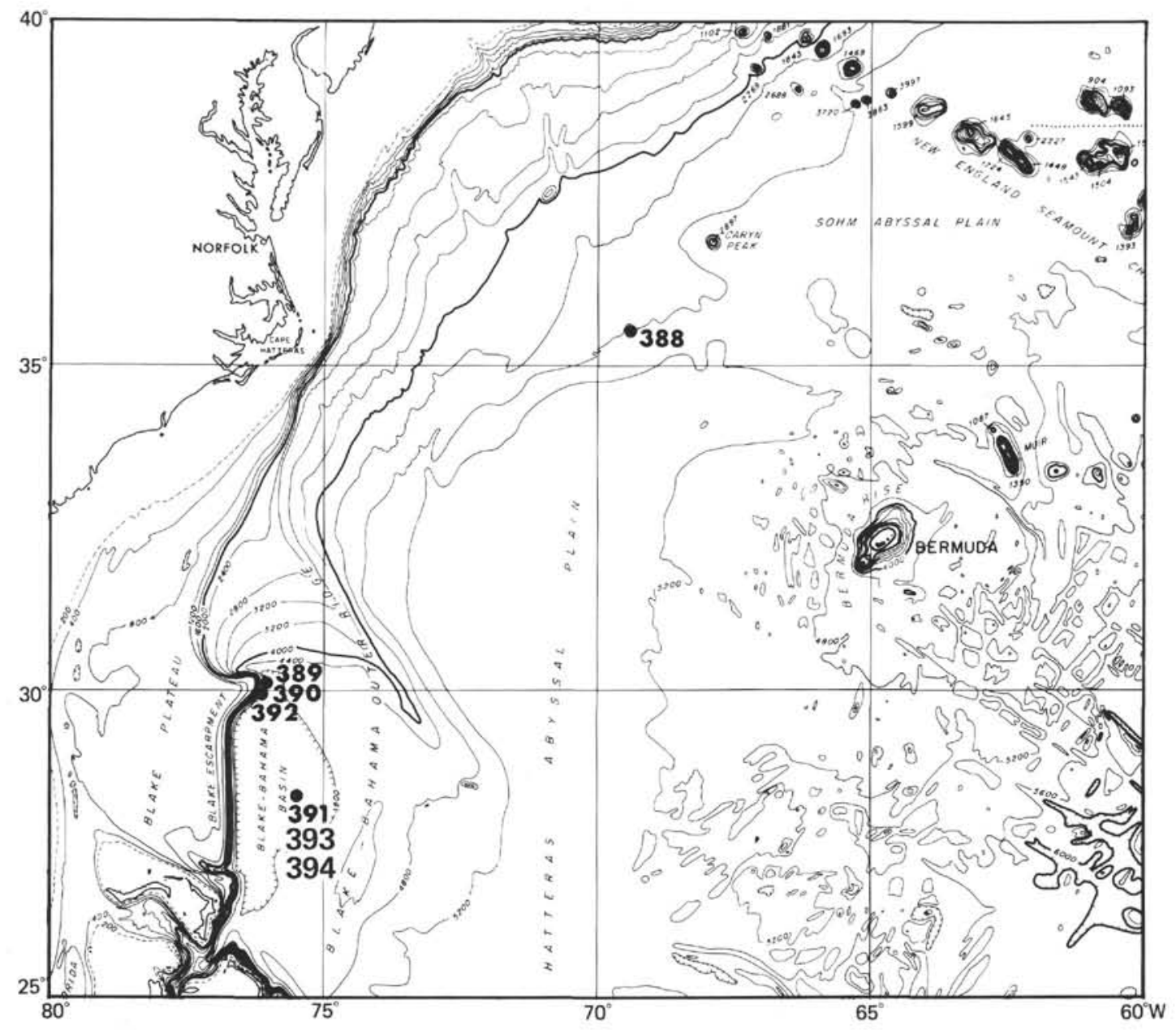

Figure 1. Map showing location of Sites 393 and 394.

the forces exerted by the main shaft and thrusters were calibrated for use in the positioning program.

We approached Site 393 from the northwest on 11 November and at about 1030 hours, detected the $13.5-\mathrm{kHz}$ beacon from old Site 391 on the PDR record. The Challenger then steamed about one mile farther southeast and dropped a $16-\mathrm{kHz}$ beacon at 1047 hours. Site 393 is located at $28^{\circ} 11.80^{\prime} \mathrm{N}, 75^{\circ} 35.94^{\prime} \mathrm{W}$; water depth is 2616 fathoms, corrected to 4951 meters at the hydrophones and 4967 meters by a mudline core retrieved at 1828 hours on 12 November.

The bit was washed in to 5020 meters; the final 2 meters were penetrated with difficulty and we considered the sediment suitable for landing the casing shoe. The hole was consequently terminated at this depth and the drill string was pulled. On 15 November, after two days of rough weather, we prepared to lower the re-entry cone and at 1315 hours on 16 November, Hole 393A was spudded. From November through 21 November operating time was consumed in logistics and equipment tests.

Although some of the tests were successful, we were beset with many of the same technical problems that plagued drilling at Site 391 . We successfully keelhauled the newly designed cone plus “'mud skirt," but encountered difficulties in settling the cone. Twice, rings failed to engage the cone while it was being "made up." Finally after the cone and casing were set into the sediments, the ring once again failed to engage and the casing was brought back on the drill pipe.

The sand line parted on 16 November which required that we pull the pipe and re-enter the cone. Our attempts to re-enter, however, were unsuccessful. By 21 November, we identified two targets on the sonar display; presumably the beacon and the cone, but neither showed the definitive threereflector pattern of the cone. Without its "stinger" casing, the cone was probably unstable in the soft mud and had tipped or dropped on its side. At 0525 hours, on 21 November, an unsuccessful stab was made at the supposed cone. A new hole, 393B, was spudded and casing washed in. But at about 0930 hours, the beacon failed-perhaps because we had spudded in next to it rather than the cone-and, after we unsuccessfully tried another $16-\mathrm{kHz}$ beacon, the pipe was pulled above the mudline and the site abandoned.

\section{Site 394}

Following the beacon failure at Site 393, the drill string was pulled above mudline and we dropped a $13.5 \mathrm{-kHz}$ beacon about 1000 meters south of Hole 393 at 1037 meters, 21 November 1975. (The site has a different number only because a new beacon was dropped.) By 1300 hours, the $16^{\prime}$ " casing had been washed in (about $50 \mathrm{~m}$ ) and the shifting tool was run in to release the casing from the drill string. The 


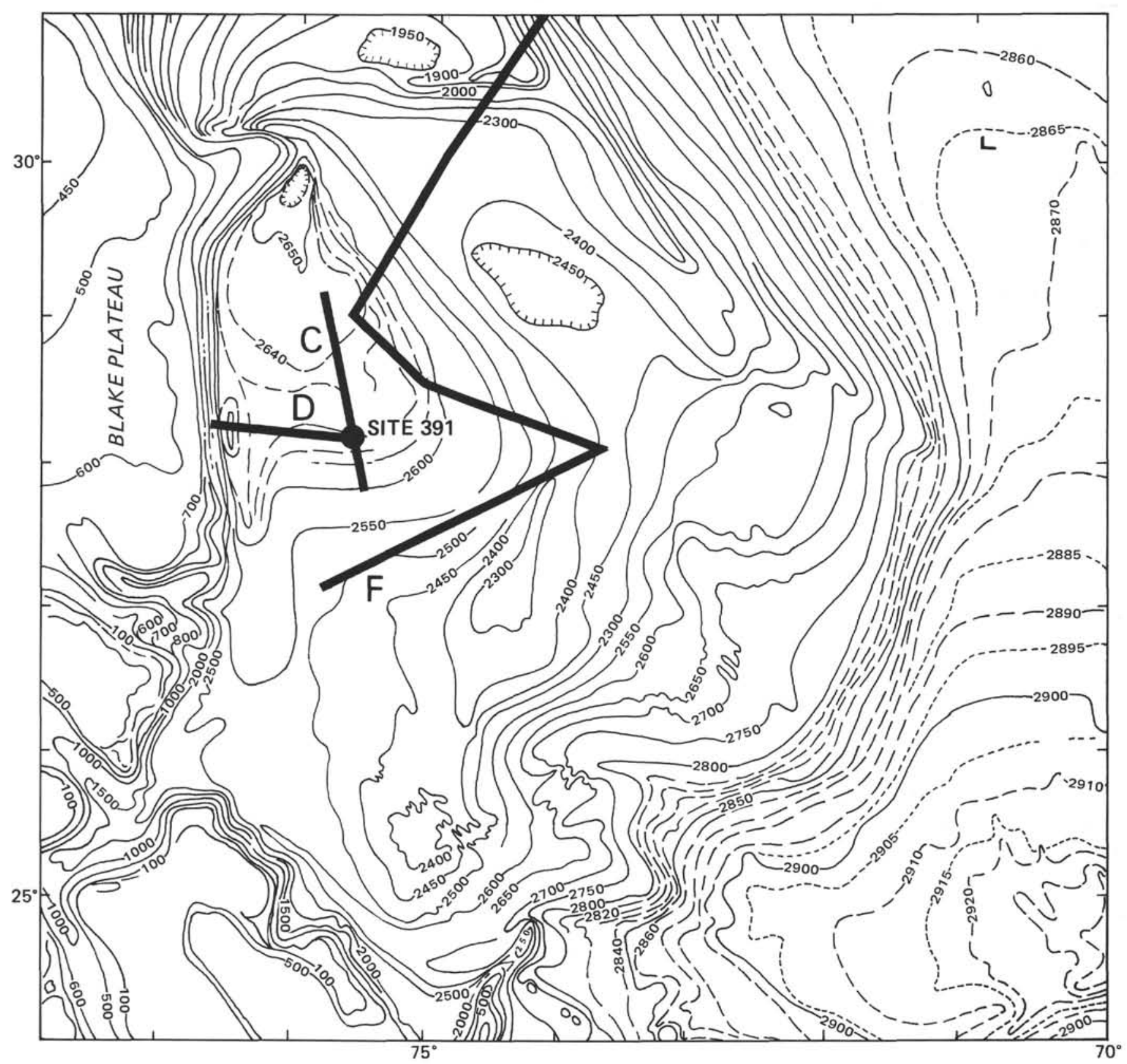

Figure 2. Detailed bathymetry of the Blake-Bahama Basin near Sites 393 and 394. Depths in fathoms are on basis of computations by E. Schneider (personal communication).

attempt was successful and Hole 394 was then drilled without coring to 83.5 meters sub-bottom, after which the pipe was tripped to remove the latching sub.

A new bottom-hole assembly with an 11' ' bit was made up and Hole 394A was spudded in at 1440 hours, 22 November. Six cores were taken between then and 1159 hours and 23 November, the deepest from 355 to 364.5 meters subbottom. Core 2, from 98.5 to 108.0 meters, was taken with the pressure core barrel which, as was the case during Leg 44, failed to function satisfactorily.

Site 394 was terminated after Core 6 was cut and the tools were laid on the deck at about 2100 hours. After about 6 hours of further calibration of the positioning system, the
Challenger departed for San Juan, Puerto Rico, at 0530 hours, 24 November 1975.

Summary of coring operations at Sites 393 and 394 are given in Table 1.

\section{LITHOLOGY}

Only two cores were recovered at Site 393: a single mudline core from Hole 393 and 8 meters of thoroughly homogenized sediment from the upper 58 meters of Hole 393 A. Both cores consisted of gray calcareous silty clay and a lighter colored upper Quaternary clayey nannofossil ooze. The ooze especially has a mixed fossil content containing Miocene (Discoaster brouweri and D. challengeri) to 


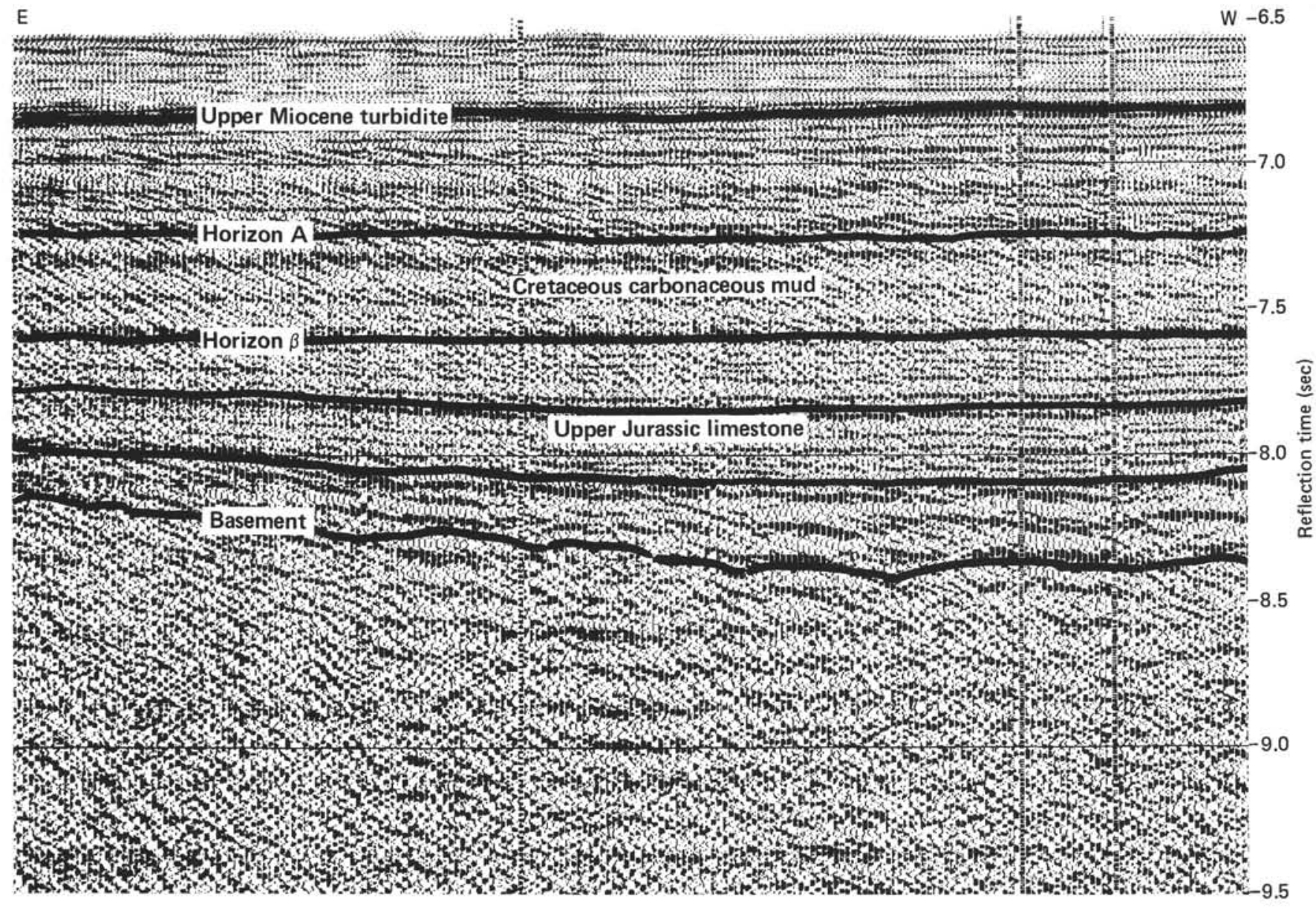

Figure 3. 24-fold multichannel seismic reflector record MC 1 made by $R / V$ Conrad across Site 391. Horizons identified on basis of interpretation by Dillon et al., 1976. (Data courtesy of IFP-USGS.) Sonobuoy interval velocities (supplied by Doherty Geological Observatory) are shown at right.

Holocene floras indicating considerable reworking from older deposits. The lithology corresponds to unit 1 of Site 391.

Six cores, recovered at Site 394, Hole 394A, correspond lithologically to units 1 and 2 of Site 391. The Miocene beds of unit 2 are pale olive-gray and light gray similar to the 500 meters of intraclastic chalk of Site 391, except that they contain somewhat fewer clay clasts. A few beds are laminated and these tend to be richer in siliceous fossils reworked from the olive and green siliceous claystones of the clasts.

The bottom half meter of Core 6 consists of olive-gray radiolarian-rich claystone, probably a boulder-sized clast. Individual flows range in thickness from a few centimeters up to more than 2 meters.

\section{SUMMARY AND CONCLUSIONS}

Sites 393 and 394 were a re-occupation of Site 391 (Leg $44)$ in the Blake-Bahama Basin. They were chosen as the site for the engineering trials because of the importance of coring the section below 1400 meters sub-bottom and because the soft bottom would provide good test for the new type re-entry cone. Numerous technological failures, however, negated any attempt at deep penetration in the time available. Cores were recovered to a depth of 364.5 meters at Hole 394A. The lower three cores come from intervals unsampled at Site 391, thus supplementing the sedimentary record. As predicted from Site 391 drilling, the cores consisted of Miocene marly chalk gravity deposits.

\section{REFERENCES}

Benson, W. E. and Sheridan, R. E., et al., 1975. Shipboard Summary for Leg 44, Site 391.

Dillon, W. P., Sheridan, R. E., and Fail, J. P., in press. Continent-Ocean Boundary in the Blake-Bahama Basin: U. S. Geol. Survey Bull.

Hollister, C. D., Ewing, J. I., et al., 1972. Initial Reports of the Deep Sea Drilling Project, v. 11: Washington (U. S. Government Printing Office). 


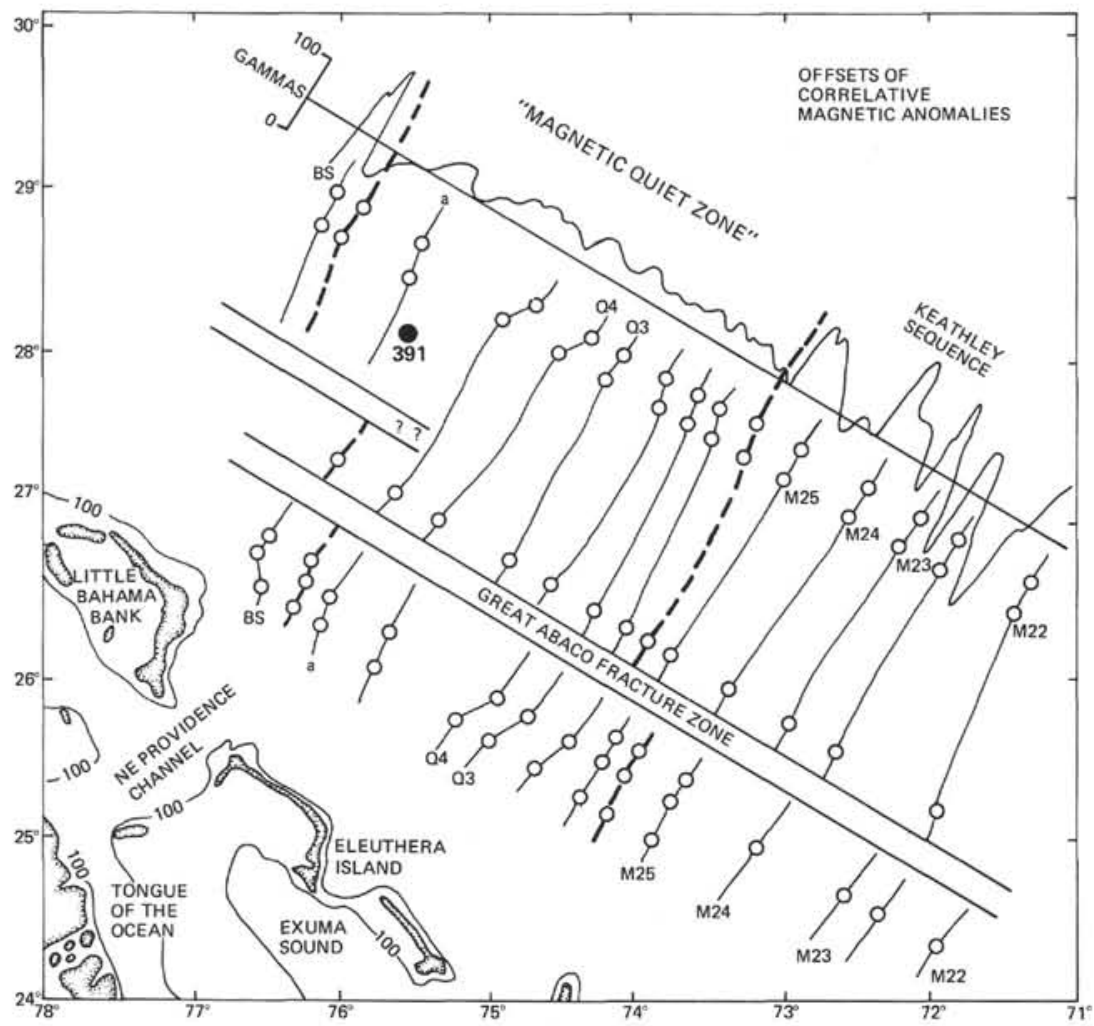

Figure 4. Location of Sites 393 and 394 relative to correlative linear magnetic anomalies of magnetic quiet zone (after Sheridan and Osburn, in press).

TABLE 1

Coring Summary, Sites 393 and 394

\begin{tabular}{|c|c|c|c|c|c|c|c|c|}
\hline \multirow[b]{2}{*}{ Core } & \multicolumn{2}{|c|}{ Cored Interval } & \multirow[b]{2}{*}{$\begin{array}{l}\text { Cored } \\
(\mathrm{m})\end{array}$} & \multirow{2}{*}{\multicolumn{2}{|c|}{ Recovered }} & \multirow[b]{2}{*}{ Lithology } & \multirow[b]{2}{*}{ Age } & \\
\hline & $\begin{array}{l}\text { Total Depth } \\
(\mathrm{m})\end{array}$ & $\begin{array}{l}\text { Sub-bottom Depth } \\
(\mathrm{m})\end{array}$ & & & & & & \\
\hline \multicolumn{9}{|c|}{ Hole 393} \\
\hline 1 & $4960.0-4969.5$ & $+1.5-8.0$ & $(9.5)$ & 4.3 & 45 & $\begin{array}{l}\text { Silty calcareous clay and } \\
\text { marly nannofossil ooze }\end{array}$ & Quaternary & \\
\hline 2 & $4950.5-4960.0$ & $+11.0-+1.5^{\mathrm{a}}$ & \multicolumn{3}{|l|}{ water } & - & - & \\
\hline \multicolumn{9}{|c|}{ Hole 393A } \\
\hline 1 & $4961.5-5020.0$ & $\begin{array}{l}0.0-58.5 \\
\text { (washed) }\end{array}$ & - & 9.5 & - & $\begin{array}{l}\text { Calcareous and siliceous clay } \\
\text { and marly nannofossil ooze }\end{array}$ & Quaternary & \\
\hline \multicolumn{9}{|c|}{ Hole 393B } \\
\hline 1 & & & 0 & 0.0 & 0 & & & \\
\hline \multicolumn{9}{|c|}{ Hole 394} \\
\hline 1 & & & 0 & 0.0 & 0 & & & \\
\hline \multicolumn{9}{|c|}{ Hole $394 \mathrm{~A}$} \\
\hline $\begin{array}{l}\text { Unit } 1 \\
1\end{array}$ & $5050.5-5060.0$ & $89.0-98.5$ & 9.5 & 3.0 & 32 & $\begin{array}{l}\text { Marly nannofossil ooze } \\
\text { and siliceous calcareous ooze }\end{array}$ & Quaternary & \\
\hline $\begin{array}{l}2 \\
3\end{array}$ & $\begin{array}{l}5060.0-5069.5 \\
5136.0-5145.5\end{array}$ & $\begin{array}{r}98.5-108.0 \\
174.5-184.0\end{array}$ & $\begin{array}{l}6.5^{b} \\
9.5\end{array}$ & $\begin{array}{l}0.3 \\
0.3\end{array}$ & $\begin{array}{l}5 \\
3\end{array}$ & $\begin{array}{l}\text { Gray clay and ooze } \\
\text { Silty clay }\end{array}$ & $\begin{array}{l}\text { Quaternary } \\
\text { Quaternary }\end{array}$ & $\begin{array}{l}\text { (Probably from above } \\
150 \mathrm{~m} \text { sub-bottom) }\end{array}$ \\
\hline \multicolumn{9}{|r|}{ 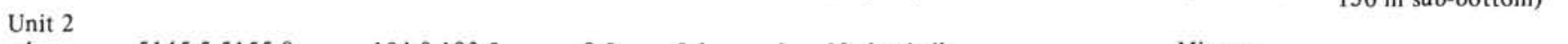 } \\
\hline 4 & $5145.5-5155.0$ & $184.0-193.5$ & 9.5 & 0.1 & 1 & Marly chalk & Miocene & \\
\hline 5 & $5240.5-5250.0$ & $279.0-288.5$ & 9.5 & 4.1 & 44 & Intraclastic marly chalk & Miocene & \\
\hline 6 & $5316.5-5326.0$ & $355.0-364.5$ & 9.5 & 9.5 & 100 & Marly chalk and siliceous clay & Miocene & \\
\hline
\end{tabular}

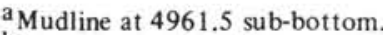

$b_{\text {Pressure core barrel. }}$ 


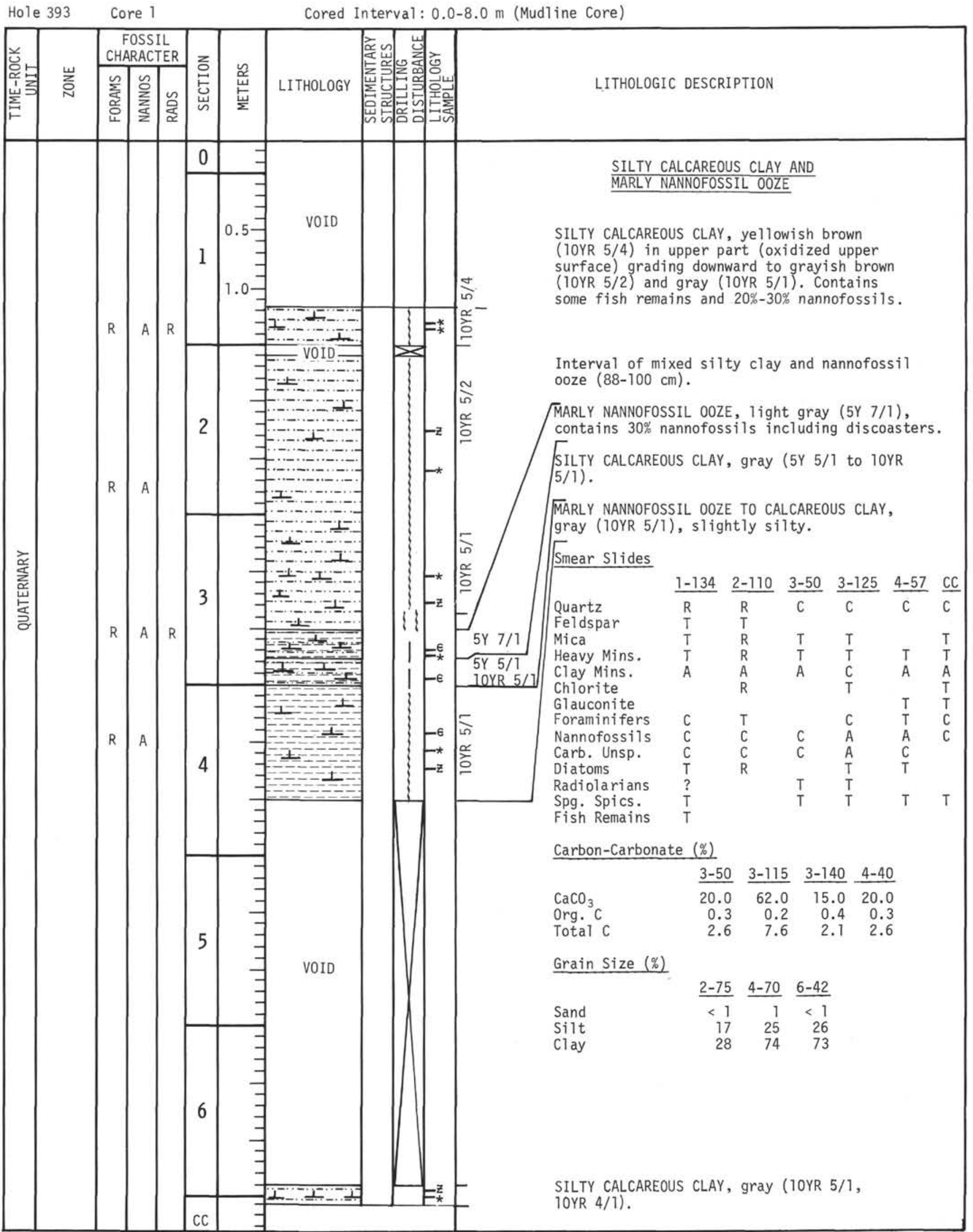




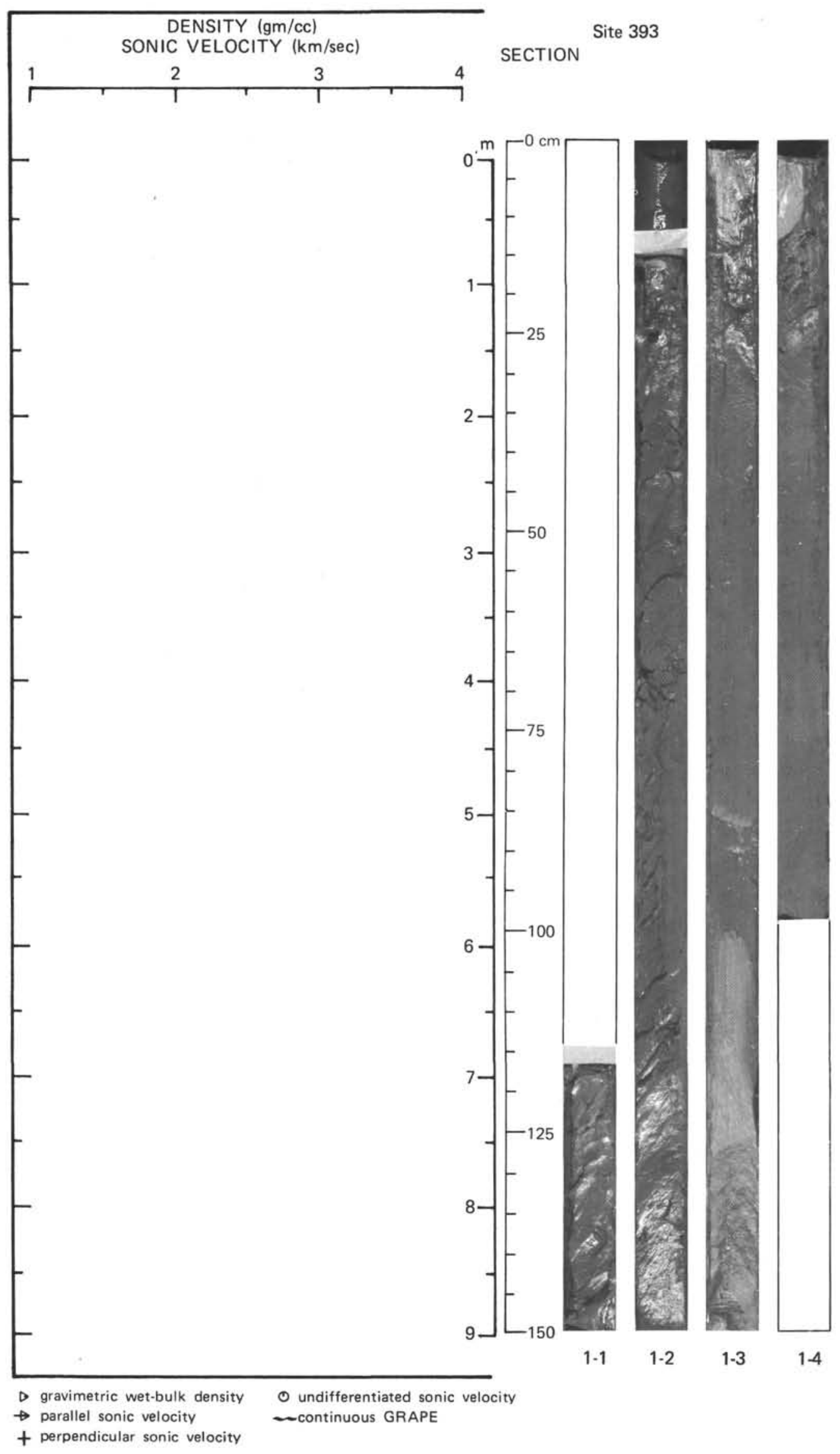




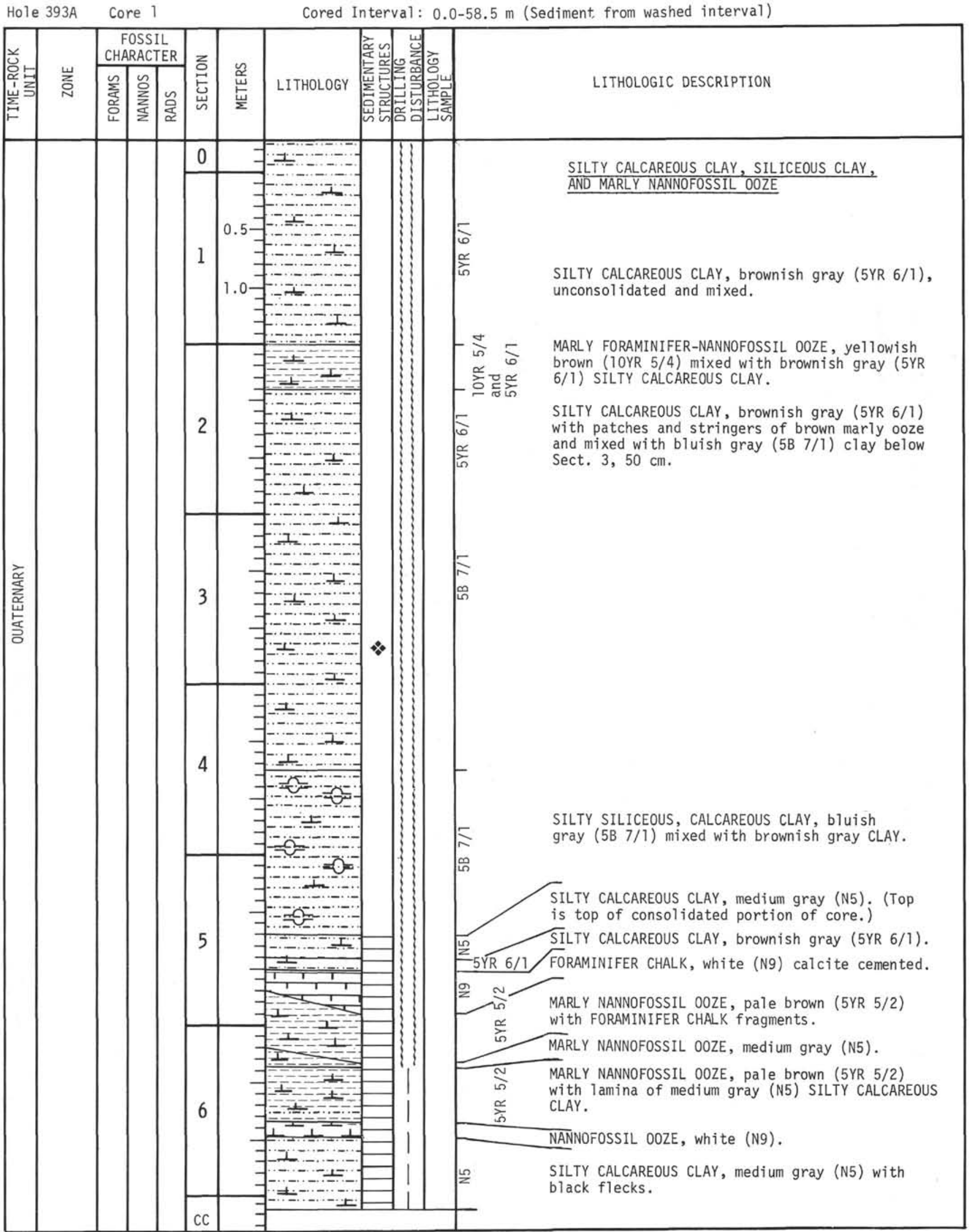




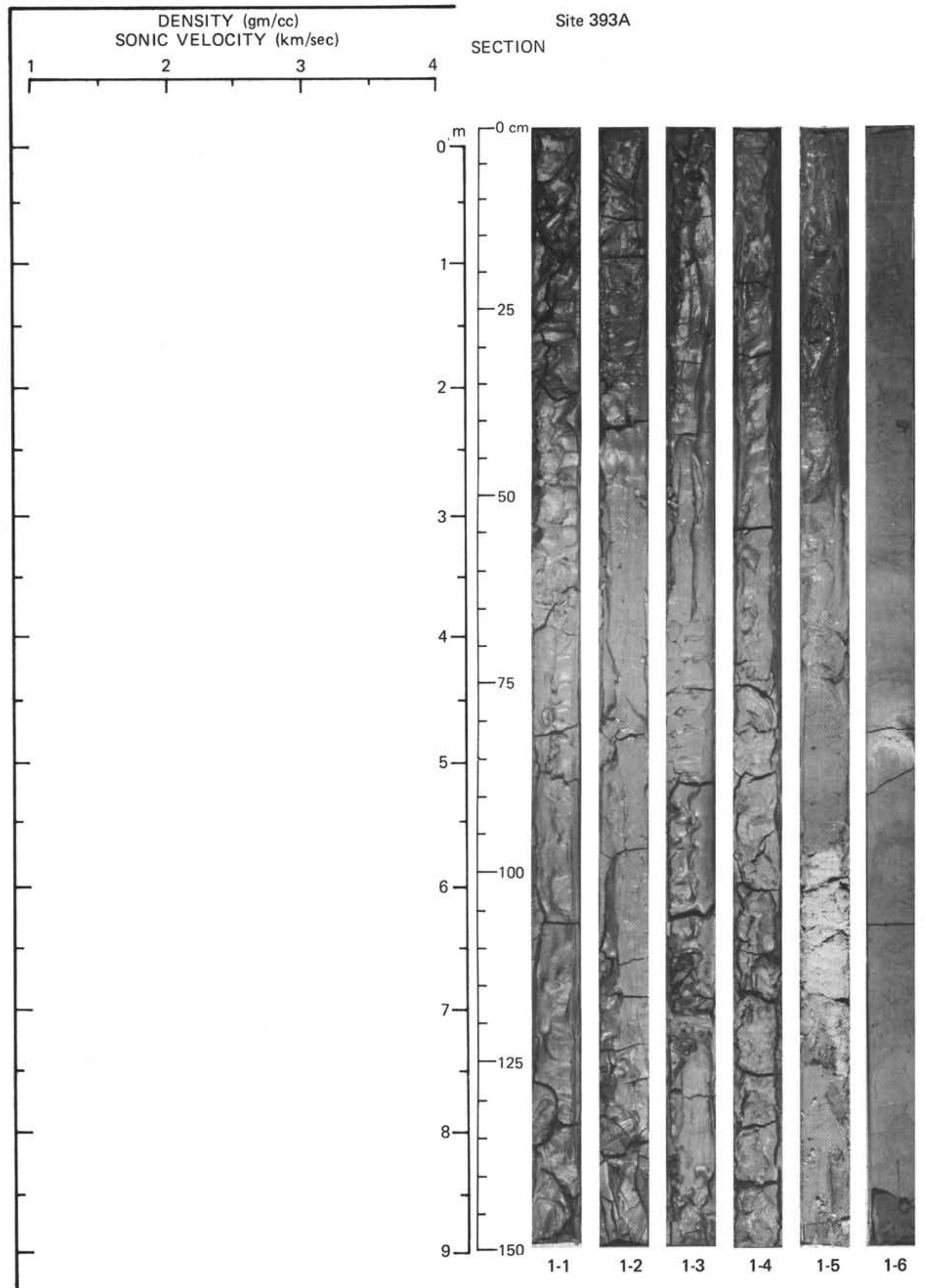

D gravimetric wet-bulk density $\odot$ undifferentiated sonic velocity

$\rightarrow$ parallel sonic velocity

〜 continuous GRAPE

+ perpendicular sonic velocity 


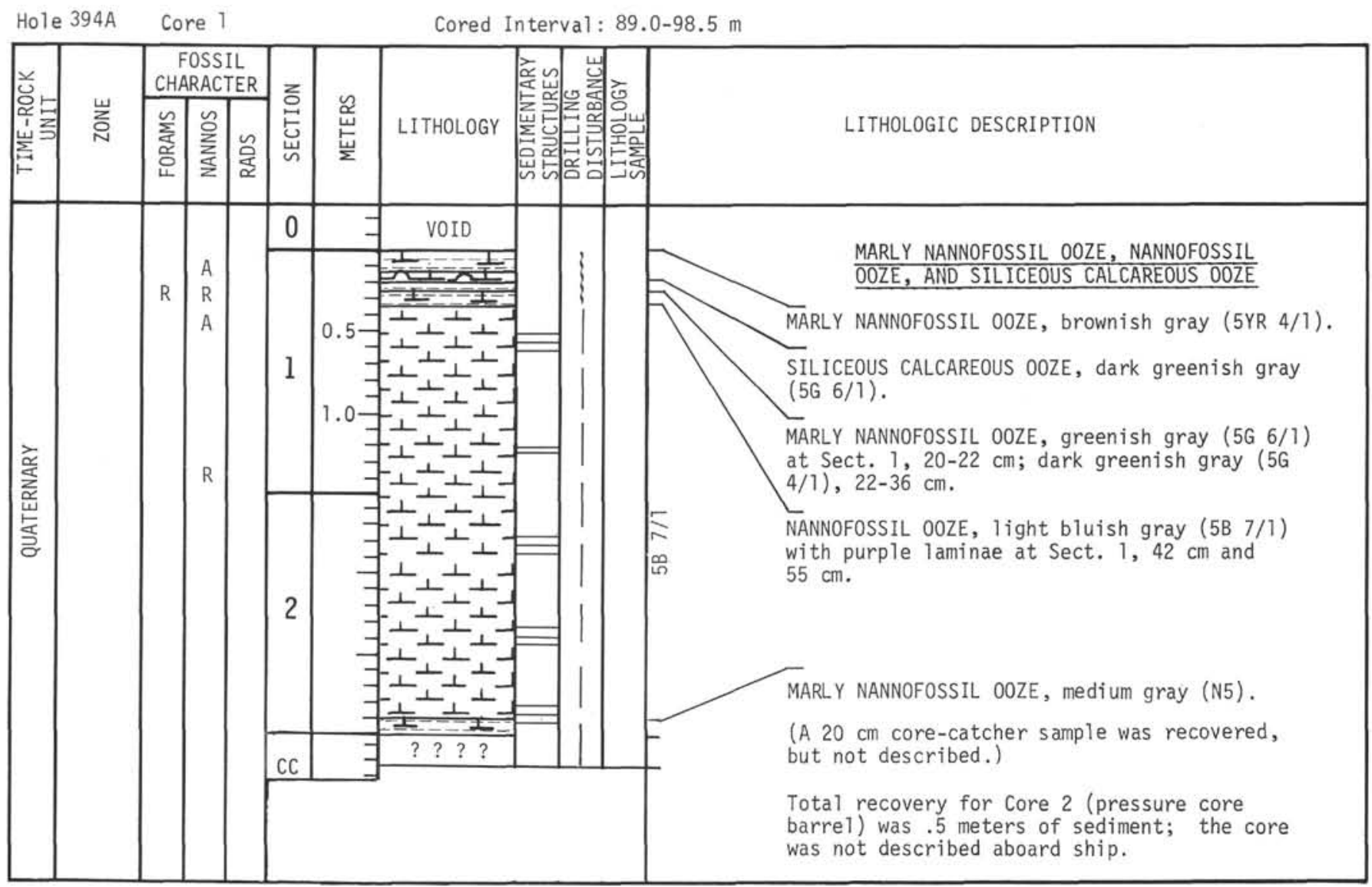

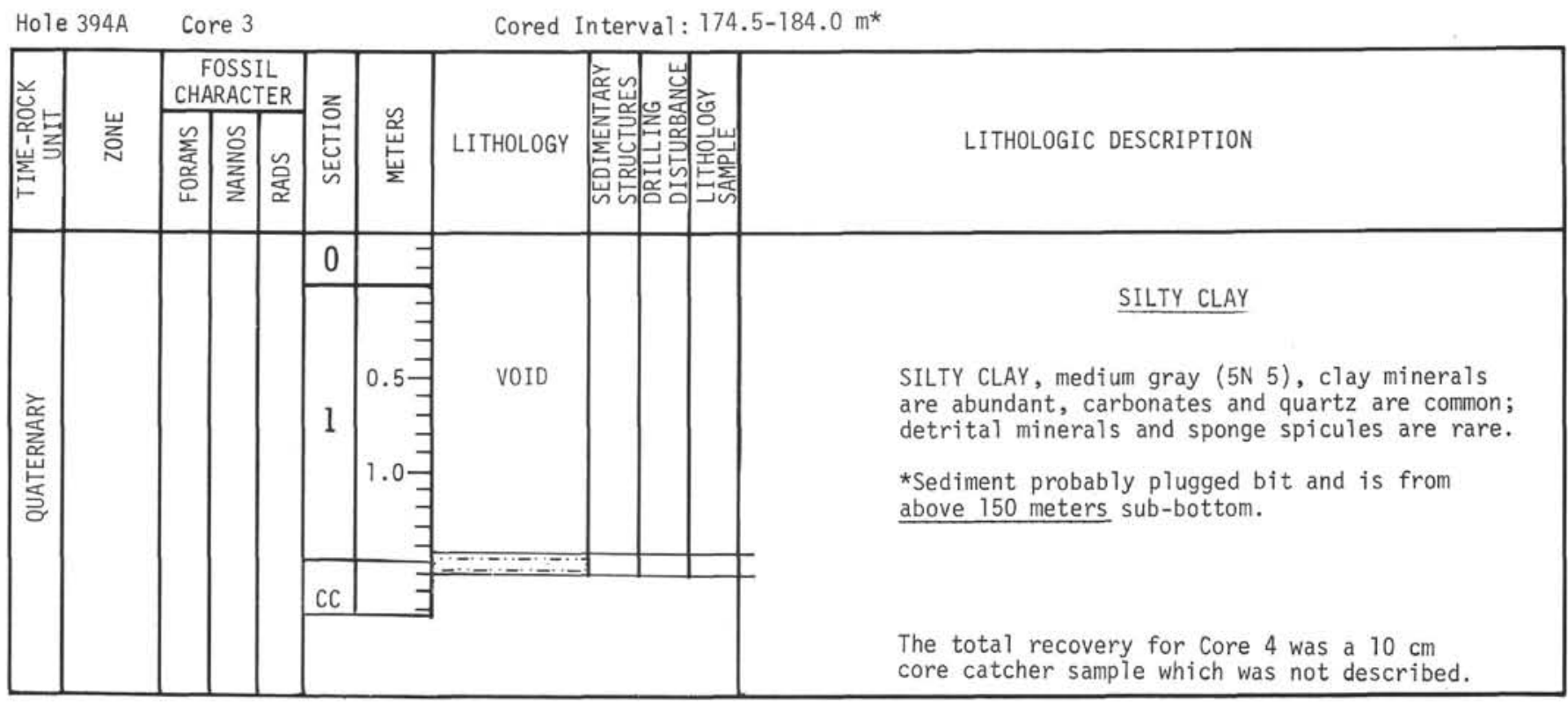



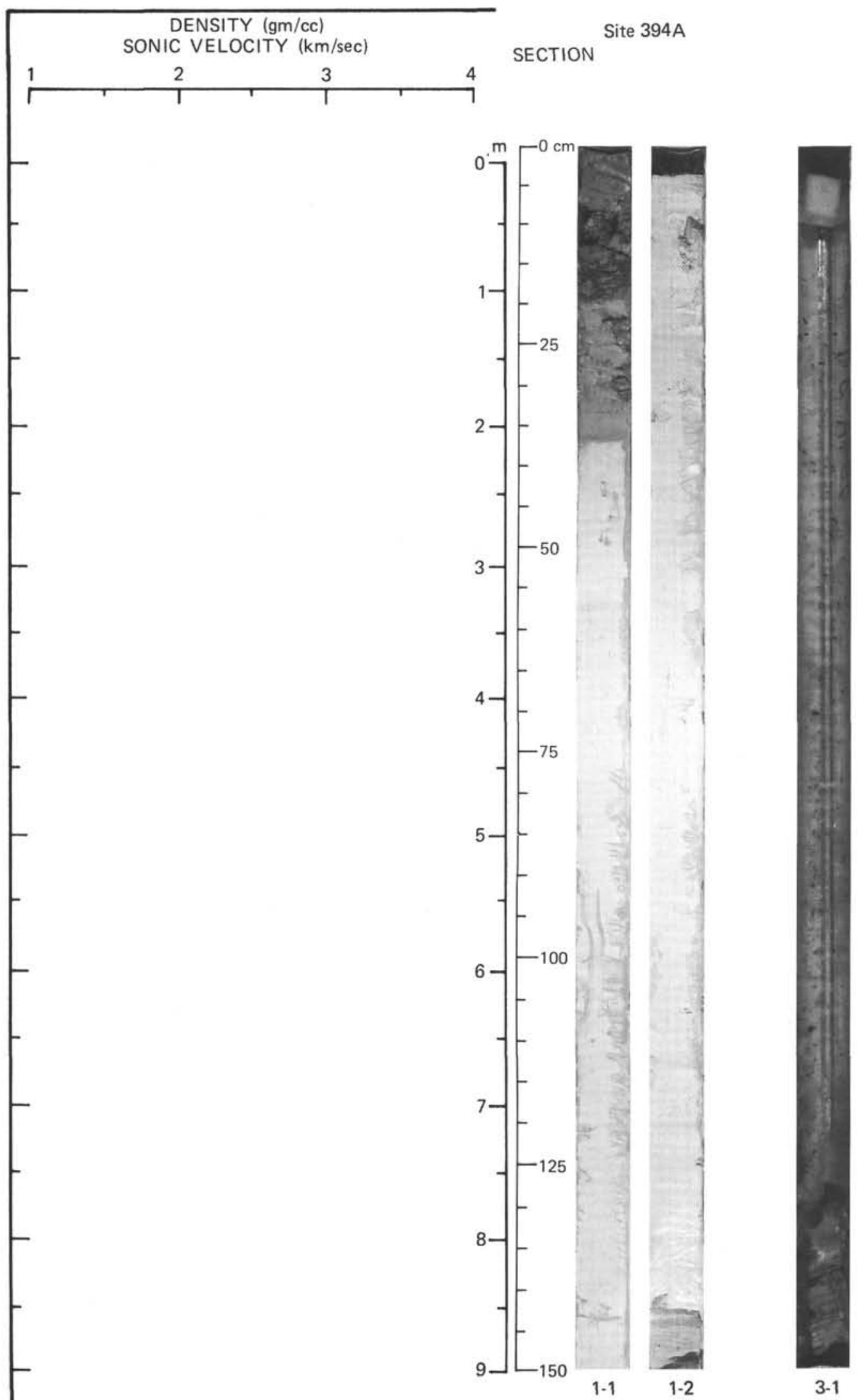

3-1

D gravimetric wet-bulk density $\rightarrow$ parallel sonic velocity

$\bigcirc$ undifferentiated sonic velocity

+ perpendicular sonic velocity 〜 continuous GRAPE 


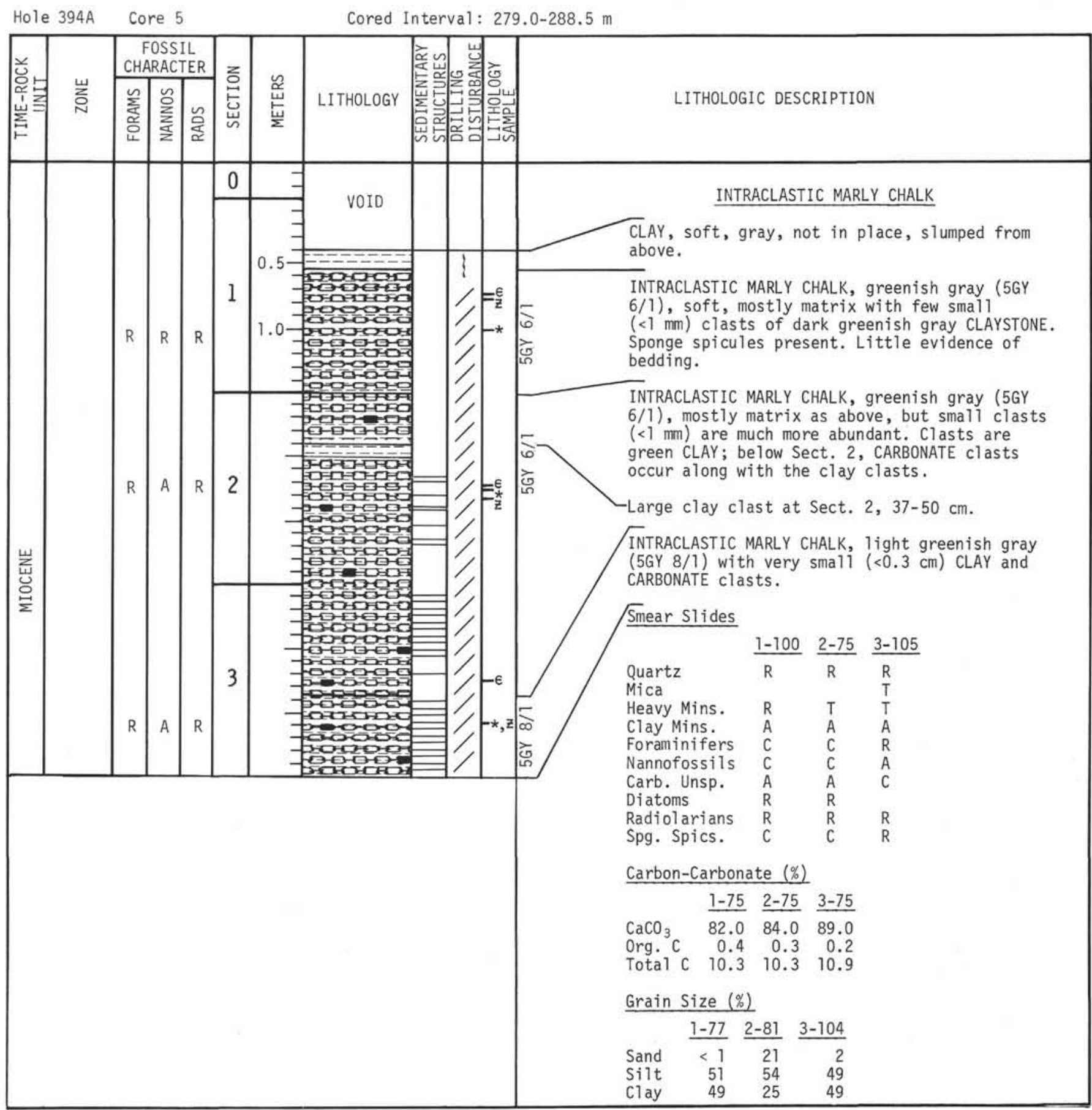




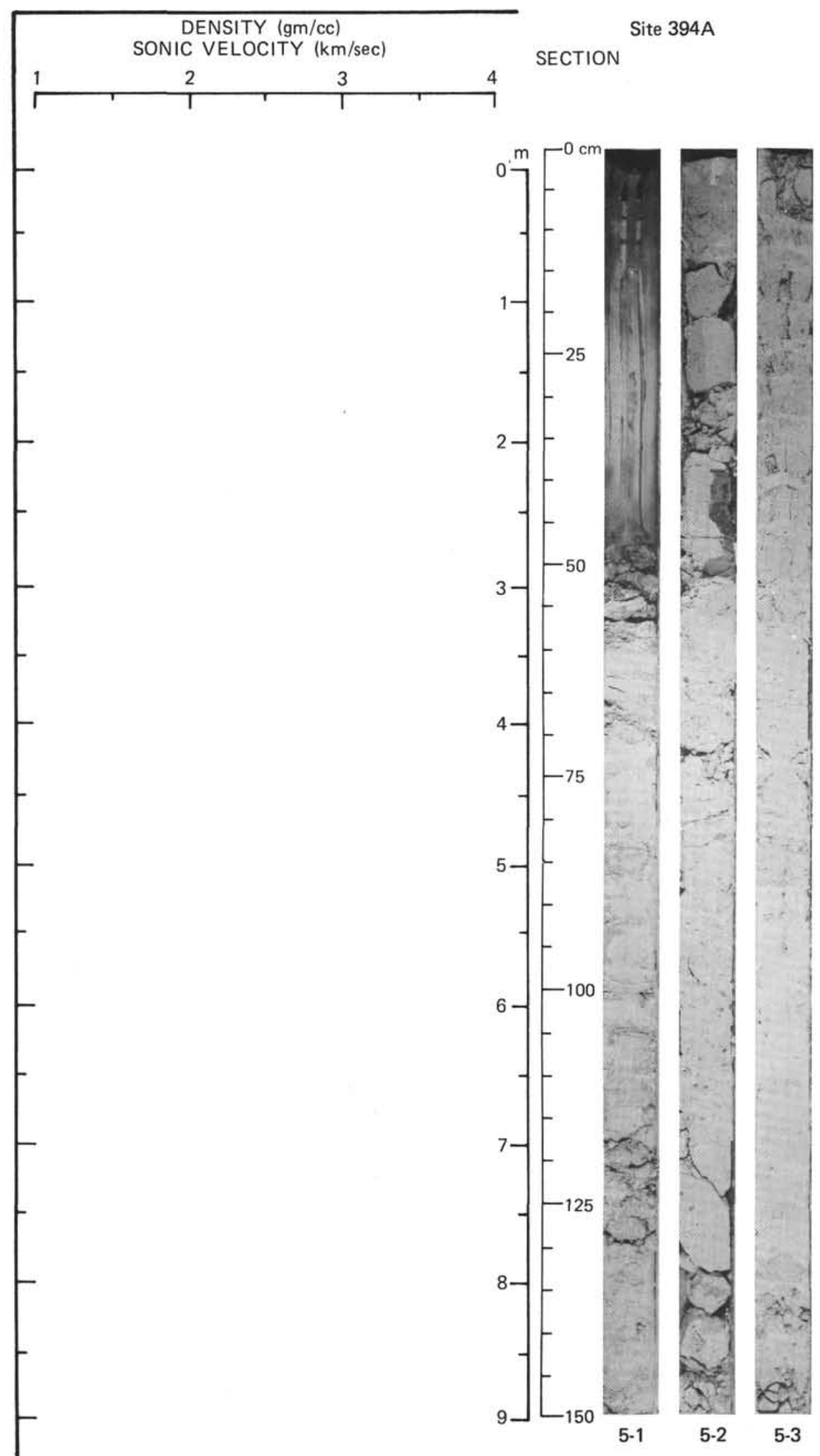

D gravimetric wet-bulk density $\odot$ undifferentiated sonic velocity

$\rightarrow$ parallel sonic velocity

〜 continuous GRAPE

+ perpendicular sonic velocity 


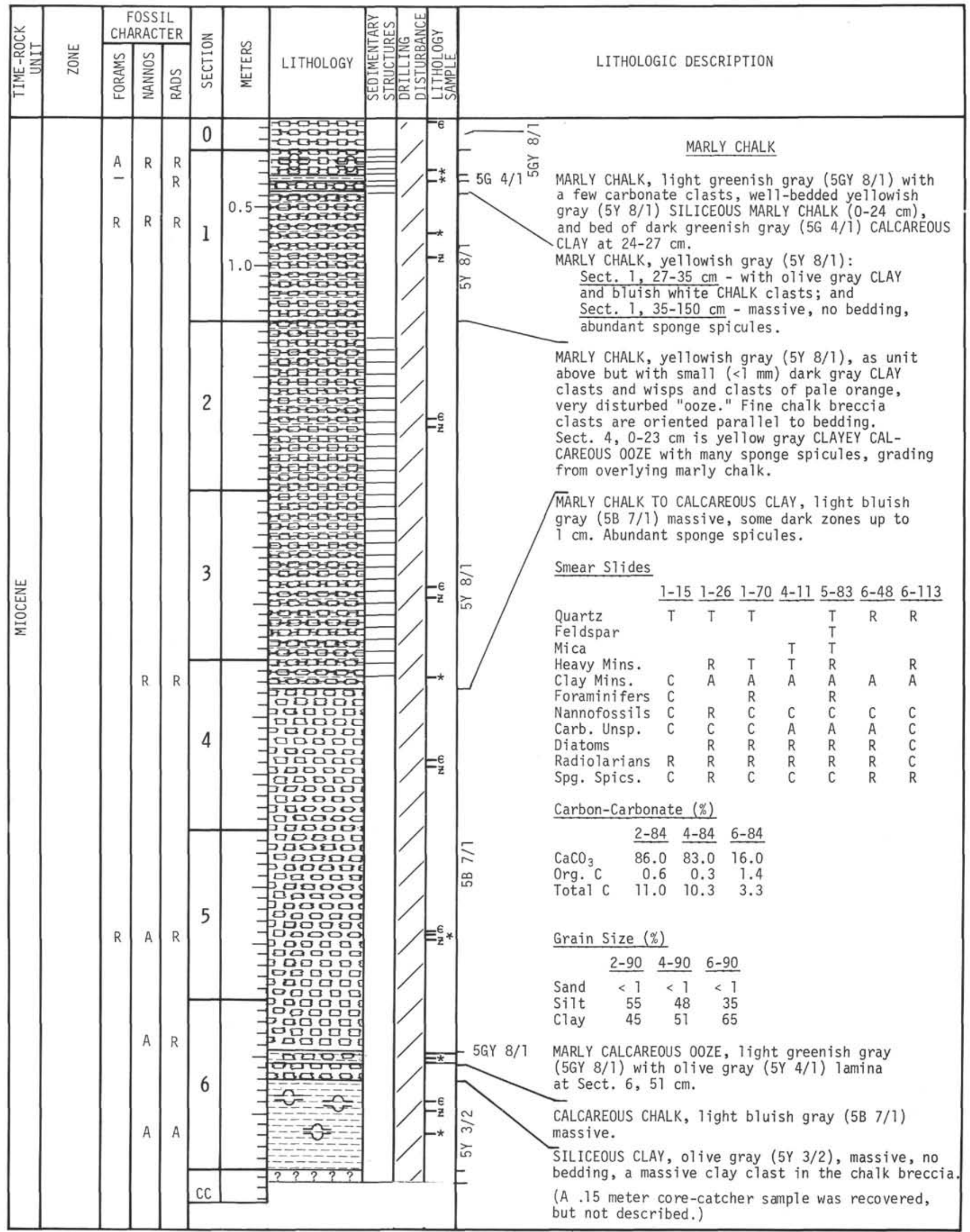




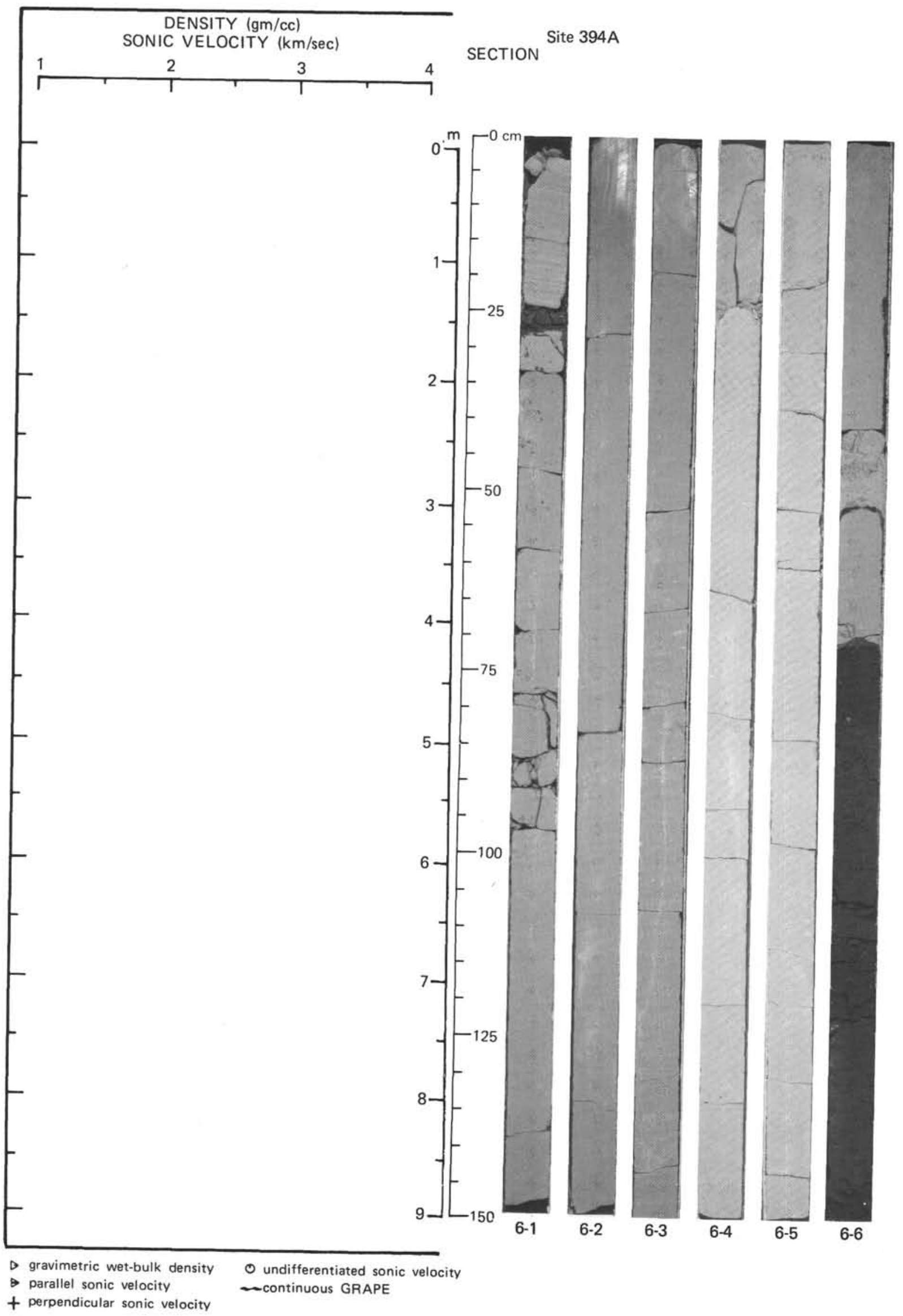

